УДК 378016:930.24(614.843)

DOI https://doi.org/10.31470/2518-7600-2021-11-246-269

THE HISTORY OF UKRAINE'S FIRE TOWERS DEVELOPMENT AS A TRAINING COMPONENT OF HIGHER EDUCATION RECIPIENT OF FIRE SAFETY IN THE WORKPLACE

\title{
ІСТОРІЯ РОЗВИТКУ ПОЖЕЖНИХ ВЕЖ УКРАЇНИ ЯК СКЛАДОВА ФОРМУВАННЯ ЗНАНЬ У ЗДОБУВАЧІВ ВИЩОЇ ОСВІТИ 3 ПОЖЕЖНОЇ БЕЗПЕКИ ВИРОБНИЦТВ
}

\section{ИСТОРИЯ РАЗВИТИЯ ПОЖАРНЫХ БАШЕН УКРАИНЫ КАК СОСТАВЛЯЮЩАЯ ФОРМИРОВАНИЯ ЗНАНИЙ С ПОЖАРНОЙ БЕЗОПАСНОСТИ ПРОИЗВОДСТВ У СОИСКАТЕЛЕЙ ВЫСШЕГО ОБРАЗОВАНИЯ}

\section{Олена Бокшиц, наук, доиент кафедри теорії та методики професійної підготовки, доцент alenabokshic@gmail.com https:// orcid: 0002-3528-5312 ДВНЗ «Переяслав- Хмельнищький державний педагогічний університет імені Григорія Сковороди» вул. Сухомлинського, 30 , м. Переяслав, Київька обл., Україна, 08401} доцент, кандидат історичних Assistant Professor, Ph.D. in
Olena Bokshyts, Historical Sciences, Associate Professor of the Department of Theory and Methods of Vocational Training, Associate Professor alenabokshic@gmail.com https://orcid: 0002-3528-5312 Pereiaslav-Khmelnytskyi Hryhorii Skovoroda State Pedagogical University, 30, Sukhomlynskoho Str., Pereiaslav, Kyiv Reg., Ukraine, 08401 


\section{Ірина Каменська,}

доиент, кандидат

сільськогосподарських наук, дочент кафедри теорії та методики професійної підготовки ikamenskay1@gmail.com https:// orcid: 0000-0003-28725065 ДВНЗ

«Переяслав-Хмельнищький державний педагогічний університет імені Григорія Сковороди» вул. Сухомлинського, 30 , м. Переяслав, Київська обл., Україна, 08401

\section{Iryna Kamenska,} Assistant Professor, Ph.D. in Agricultural Sciences, Assistant Professor of Department of Theory and Methods of Vocational Training ikamenskay1@gmail.com https:// orcid: 0000-0003-28725065 Pereiaslav-Khmelnytskyi Hryhorii Skovoroda State Pedagogical University, Ukraine 30, Sukhomlynskoho Str., Pereiaslav, Kyiv Reg., Ukraine, 08401

\section{ABSTRACT}

In today's world, health is a fundamental part of every person's life that directly affects their well-being, well-being, mental and emotional well-being. Health is a valuable indicator of the civilization of modern society, one of the main components of national development in the world.

In the difficult conditions of the current pandemic in the world, modern society still needs competent professionals who could be competitive in the labor market, would change dramatically and organize an active life position, who would quickly make logical decisions, be able to rationally organize their living from the standpoint of preserving, strengthening the health of both themselves and others, to create and ensure safe living and working conditions at work and in everyday life, to be able to prevent dangerous situations that threaten people's lives.

It is known that the fire danger is one of the oldest threats and problems faced by mankind throughout life on earth.

Fire has left its mark on the history of all eras and peoples. 
Thousands of towns and villages have disappeared from the face of the earth in giant tongues of flame. The priceless creations of the minds and talented hands of previous generations have turned to dust. Throughout the centuries, fire has destroyed millions of lives. Due to their tragic consequences, fires were not inferior to epidemics, droughts and other disasters.

The total number of fires on our planet has reached 5.5 million a year, every 5 seconds a fire breaks out somewhere. Therefore, it is not surprising that today fires are really becoming a serious problem.

In the current realities of the 21 century, modern man is already armed with knowledge and the most powerful equipment, and can already compete at the appropriate level with fire, acquire and form knowledge about fire safety, knowledge obtained in higher education. It is in the institutions of higher education that the formation of knowledge takes place, the training of future professionals as propagandists and teachers in the fight against fires and the safe organization of life.

The article considers the historical moments of origin and development of architectural monuments on the territory of Ukraine, which in their time played an important role and function in ensuring the safety of life of the Ukrainian people and served as fire towers (kalancha). The essence of the formation of knowledge on fire safety of industries in the study of historical aspects of the development of fire towers in Ukraine is revealed.

Formation of knowledge in students of higher education institutions on fire safety of industries provides the development of skills, abilities (competencies) for effective professional activity by ensuring optimal fire safety management at enterprises (objects of economic, economic and scientific-educational activities), the formation of students are responsible for personal and collective safety, the development of health-preserving competencies and awareness of the need for mandatory implementation in full of all measures to ensure occupational safety in the workplace. 
It is educational institutions in particular higher, regardless of the types of their orientation, is the center where the formation of knowledge, skills and abilities of students in the study of fire safety in particular. A person with higher education, who has a high level of health-preserving competence, is a promoter of a healthy lifestyle and directs his knowledge and skills to safe working conditions.

Keywords: knowledge formation, students, discipline, fire safety, higher education institution, fire tower, fire.

Постановка проблеми. Пожежна небезпека одна iз найдревніших загроз та проблем із якою стикається людство протягом всього земного життя. Перші державні акти якими було врегульовано питання запобігання пожежам взяли свій початок із Стародавнього Китаю.

На теренах України розвиток пожежної справи, охорони та пожежної безпеки в цілому має тисячолітню історію становлення. Ще від часів формування законодавства на основі Магдебурзького права, що стало важливим чинником державного регулювання у XIV-XV ст., одним iз найголовнішим способом виявлення пожеж був спосіб спостереження з найвищих точок міських мурів (у подальшому пожежні каланчі). Такий спосіб був довготривалий час основним засобом спостереження та повідомлення про пожежу.

Сьогоденні заклади вищої освіти надають можливість молоді професійно знайомитися та в подальшому навчанні формувати знання, використовувати уміння й навички 3 пожежної безпеки для безпечної праці та життя людей зокрема. Пожежна безпека галузь науки і техніки, що комплексно займається виявленням і вивченням процесів, закономірностей, чинників виникнення пожеж та їх попередження, динаміки пожеж у конкретних умовах, небезпечних факторів пожеж, розробленням методів і засобів протипожежного захисту для зниження пожежної небезпеки, методів гасіння й ліквідації пожеж (Бокшиц, 2018). 
Аналіз останніх досліджень і публікацій. Питаннями історичного дослідження різноманітних особливостей виникнення пожежної справи займалися такі відомі радянські, українські та зарубіжні фахівці, як: В.С. Нехаєв, А.П. Рожков, Г.В. Смирнов, А.Г. Томіленко, Я.Я. Щербина та ін. При цьому дослідження історичного підгрунтя щодо розвитку пожежних веж на території українських земель були висвітлені частково. Багато нагальних питань із формування знань здобувачів вищої освіти та професійної підготовки спеціалістів 3 пожежної безпеки розкривають у своїх працях В.А. Доманський та Д.В. Зеркалов.

Метою статті є теоретичний аналіз особливостей формування знань з пожежної безпеки виробництв у здобувачів вищої вищої освіти при вивченні основних етапів розвитку пожежних веж України 3 моменту їх виникнення до теперішнього часу.

Виклад основного матеріалу. Протягом всього життя слово «пожежа» завжди викликає у людей всього світу велику тривогу і хвилювання. І це зрозуміло, тому що вогонь нерідко знищується майно, руйнує житлові будинки, школи, i громадські будівлі, об'єкти господарської діяльності, завдає значної шкоди навколишньому середовищу і шкоди людському життю.

У результаті постійного моніторингу щодо забезпечення рівня безпеки на сучасних виробництвах, підприємствах, у закладах освітнього спрямування та дослідження існуючих ризиків соціологічним (опитування здобувачів вищої освіти, професорсько-викладацького складу), статистичним (аналіз надзвичайних подій, що сталися на виробництвах країни протягом останніх років) та іншими методами складено перелік найпоширеніших небезпек, які становлять або можуть становити загрозу. Одне із перших місць у списку займає пожежа та її наслідки (Рожков, 1999).

За часів СРСР наша держава у спадок отримала потужну розгалужену систему освіти 3 високоідейною на той час 
інфраструктурою. Але у сучасному мобільному сьогоденні вона потребує суттєвих змін і модернізації, оскільки за якісними та кількісними показниками не завжди відповідає рівню освіти країн Свропи та світу, має застарілий зміст, форми і методи навчання, інші перешкоди і проблеми. Для того, щоб сучасна вища українська освіта XXI століття була конкурентоспроможною, досягла світового рівня, необхідно усунути всі недоліки i проблеми, а також провести деталізований аналіз минулих років, досконало знати досвід історичного розвитку як вищої освіти в Україні та паралельно 3 існуючою проблемою пожежної безпеки зокрема. Тільки знання попередніх систем освіти, їх негативних і позитивних сторін дозволить бути сучасній українській системі вищої освіти найбільш доцільною і досконалою, що у подальшому дасть розвиток для формування знань у здобувачів вищої освіти 3 пожежної безпеки зокрема.

Аналізуючи існуючі заходи пожежної безпеки було встановлено слабкі місця, які потребують ретельного дослідження та усунення. Одне 3 них, це відсутність в учасників освітньо-виховного процесу знань та недотримання ними вимог пожежної безпеки, проблеми вивчення правил пожежної безпеки.

Проблема формування знань у здобувачів вищої освіти 3 пожежної безпека виробництв набула особливої гостроти й актуальності в сучасних умовах. Однією з основних причин $є$ мала кількість годин, що відводиться на вивчення дисциплін 3 пожежної безпеки зокрема з історії розвитку пожежної безпеки, та неможливість організації повноцінного практичного тренінгу з відпрацювання отриманих теоретичних знань під час лабораторних занять (Бокшиц, 2016).

Щоб сформувати в учасників освітньо-виховного процесу свідоме та відповідальне ставлення до питань особистої безпеки й безпеки тих, хто їх оточує, навчити здобувачів вищої освіти розпізнавати й оцінювати потенційні небезпеки, визначати шлях надійного захисту від них, уміти надавати 
допомогу в разі потреби собі та іншим, а також оперативно ліквідовувати наслідки прояву небезпек у різноманітних сферах людської діяльності потрібні знання історичного становлення пожежної безпеки, нові креативні форми навчання, перегляд навчальних програм з безпекових дисциплін та збільшення часів викладання дисципліни з пожежної безпеки виробництв (Бокшиц, 2016).

У закладах вищої освіти формування знань 3 пожежної безпеки виробництв при вивченні історичних моментів розвитку пожежної справи та розвитку пожежних веж зокрема, відбувається шляхом вивчення принципів і методами забезпечення пожежної безпеки об’єктів комерційної і господарської діяльності на стадії проектування, будівництва й експлуатації. Формування знань базується на знаннях отриманих студентом при вивченні соціально-економічних, загальнонаукових і спеціальних дисциплін і започатковує у студентів професійні вміння та навички.

Слід відмітити, що на теперішній час спеціальних досліджень щодо формування знань у студентів з пожежної безпеки виробництв у закладах вищої освіти, науковцями досліджено мало. Тож актуальність набуття здобувачами вищої освіти системи знань з пожежної безпеки є безсумнівною.

Нині, основним навчально-пізнавальним підручником знань та нормативно-правовою базою професійної діяльності фахівця з пожежної безпеки є Постанова Кабінету Міністрів України від 26.07.94 р. (№ 508) «Про заходи щодо виконання Закону України «Про пожежну безпеку», якою затверджено Положення про державну пожежну охорону та Правила обліку пожеж, а також Перелік міністерств і відомств, на об'єктах яких створюються підрозділи відомчої пожежної охорони, «Типове положення про відомчу пожежну (пожежно-сторожову) охорону», Положення про організацію роботи органів державного пожежного нагляду (Доманський), (Панченко), (Підгайний). 
Для грунтовного пізнання, засвоєння студентами знань 3 пожежної безпеки виробництв, формування фахових компетентностей у закладах вищої освіти питання пожежної безпеки повинні відображатися не тільки в підручниках «Безпека життєдіяльності», «Основи охорони праці» i «Цивільний захист» а й вивчатися на заняттях 3 інших дисциплін, а саме: «Вступ до спеціальності», «Технічна механіка рідин та газу», «Електротехніка», «Електробезпека та запобігання аваріям в електроустановках», «Теорія горіння та вибуху», «Системи контролю небезпечних та шкідливих виробничих факторів», «Безпечна експлуатація будівель і споруд», «Безпечна експлуатація інженерних систем», «Організація наглядової діяльності в галузі охорони праці» та інші (Бокшиц, 2016).

Одними із основних завдань формування знань 3 пожежної безпека виробництв у закладах вищої освіти є: вивчення історії розвитку пожежної справи і засобів боротьби 3 нею, навчити студентів: ідентифікувати основні причини пожеж, пожежну небезпеку агрегатів та установок, що розміщені у приміщенні (будівлі, споруді); визначати пожежовибухонебезпечні показники речовин і матеріалів; контролювати нормативні вимоги щодо утримання території, протипожежних розривів, джерел протипожежного водопостачання; прогнозувати можливість і наслідки не виконання передбачених законодавством вимог пожежної безпеки; використовувати нормативно-правову базу для захисту об'єктів від виникнення можливих пожеж і боротьби 3 ним якщо вони виникли; розробляти організаційні заходи і застосовувати технічні засоби захисту від дії небезпечних факторів пожеж; запобігати виникненню пожеж, а в разі їх виникнення приймати адекватні рішення та виконувати дії, спрямовані на їх ліквідацію; вимагати від працівників використовувати у своїй практичній діяльності заходи пожежної безпеки, яких необхідно дотримуватися, стаючи до роботи, у процесі роботи та після їі закінчення з метою 
запобігання виникнення пожеж; планувати використання та впроваджувати засоби зв'язку, сигналізації, які є на об'єкті, найближчих апаратів телефонного зв'язку, сповіщувачів пожежної сигналізації, пристроїв для подання звукових сигналів пожежної тривоги, систем сповіщення та керування евакуацією людей; утворювати пожежнотехнічні комісії і добровільних пожежні дружини, за допомогою яких здійснювати постійний моніторинг пожежної безпеки (Підгайний, 2009).

Вагомі причини протипожежної проблематики потребують застосування невідкладних заходів із вдосконалення системи освітньо-виховного процесу зі здобувачами вищої освіти у сфері пожежної безпеки з метою реальних позитивних зрушень в підвищенні ефективності пожежобезпечної культури в сучасних умовах, що сприятиме досягненню передового світового рівня захисту молоді та людства від пожеж. Життєво необхідно озброїти молодь знаннями, вміннями і розумінням важливості збереження власного життя та здоров'я. Викладачі дисциплін безпекового циклу повинні дохідливо розповідати про необхідність виконання правил пожежної безпеки, пояснювати як слід себе поводити при виникненні пожежі, що треба враховувати насамперед, звертати увагу на, здається, зовсім неістотні дрібниці, які, як засвідчує практична діяльність пожежників, набувають фатального характеру, визначаючи, чи вдасться людині врятувати здоров'я, а то й життя.

Для розуміння ситуації пожежної безпеки у сучасних реаліях, потрібно бездоганно володіти фактами минулого. Тому саме навчання заходам пожежної безпеки є основним чинником у попередженні пожеж, а формування знань пожежобезпечної поведінки - основою правильного усвідомлення небезпеки пожеж i недопущення пожежонебезпечних ситуацій у майбутньому.

Історія розвитку пожежної справи (пожежної безпеки людства) безпосередньо пов'язана із необхідністю 
запровадження заходів державного регулювання відповідному до існуючого, у кожний історичний період, рівня суспільної небезпеки, пов'язаного із загрозою пожеж, а також громадськополітичного та соціально-економічного розвитку суспільства. Сфера дії правових актів щодо врегулювання питань боротьби 3 пожежами розширювалась, а в окремих випадках визначалась окремими законами (Бокшиц, 2018).

Починаючи 3 XIII ст. боротьба 3 пожежами почала здійснюватися як за напрямом попереджальних мір законодавчого характеру, так і за напрямом мір охоронного порядку. Все ж, за проведеним історичним аналізом з'ясувалося, що перші протипожежні заходи мали випадковий характер. Закони та укази, що видавалися, були пов'язані більше із мірами покарання винних і мірами охорони від пожеж, але не із загальною організацією заходів постійної боротьби з вогнем (Смирнов, 1996).

Протягом XIV-XV ст., на українських землях формується законодавство на основі Магдебурзького права, що стало важливим чинником державного регулювання.

Магдебурзьке право передбачало такі постулати запобігання пожежам:

- затвердження міською радою «вогневого порядку» i суворе його дотримання;

- запровадження на вежі ратуші цілодобової сторожі, яка у випадку пожежі повинна сповіщати про лихо і вказувати напрямок, де воно трапилося;

- кожне місто, залежно від величини, повинно бути поділено на дільниці під контролем супер-інтендантів. У їх обов'язки входить піклування, аби всі спроможні брали участь у рятувальних акціях. Хто ухилявся від цього обов'язку, підлягали суворому покаранню;

- мешканці кожної дільниці повинні знати свої обов'язки на випадок пожежі і мати відповідні знаряддя, із якими прибувають на пожежу; 
- кожен будинок повинен мати в постійній готовності засоби гасіння вогню (Смирнов, 1996).

У другій половині XVII століття за часів Гетьманщини пожежна справа на теренах українських земель отримала подальший розвиток, а правові документи можливо вважати першими документами організації пожежного нагляду, відповідно до яких встановлювались контроль за протипожежними заходами при будівництві та за дотриманням правил поводження із вогнем (Борис, 2017).

У 1809 році на доповнення до діючого Указу створені правила, згідно з якими дерев'яні будинки з пічним опаленням мали зводити на відстані не менше 25 метрів один від одного. Будівництво двоповерхових дерев'яних споруд заборонялось. Другий поверх дозволялося зводити 3 дерева лише у тому випадку, якщо перший поверх був кам'яним. За будівельні прорахунки та відсутність у будинках протипожежних перегородок архітектори та будівельники несли покарання.

Однак державні організаційні заходи щодо боротьби із пожежами не допомагали. Міста на землях Україні палали регулярно (Смирнов, 1996).

Всі ці обставини підштовхували людство до вагомих змін. Люди використовували різні методи для боротьби з пожежами, які постійно руйнували їх життя. Згубність пожеж, змушувало розпочати крок за кроком організовувати пожежну справу, метою якої стало попередження про виникнення пожеж i боротьба з ними.

Стрімко містами вітчизняних земель поширювалося зведення сторожових веж та організації пожежних охорон зокрема.

Перші спроби щодо попередження пожеж та захисту майна від вогню були застосовані в Римі близько 300 років до н. е. За свідченнями істориків, в ті часи у Римі було створено загін, одним із завдання якого було спостереження за поселенням з найвищої точки міських мурів (у подальшомукаланча), і в разі виникнення пожежі терміново та своєчасно сповіщати жителів міста про небезпеку (Беєр, 1979). 
Каланча́ - наглядова вежа при пожежній (поліцейській) частині. Застаріле значення - дозорна (оборонна) вежа. Слово запозичене з тюркських мов.

Історична розвідка вказує, що у слов'янських мовах «каланчами» спочатку звали турецькі оборонні вежі, у XIX столітті слово застосовували і щодо кавказьких сторожових веж. Одними з перших найбільш відомими в історії вважають дві каланчі на протилежних берегах Дону на підходах до Азовської фортеці. Вежі були збудовані турками у 1640-х рр. (Нехаєв, 1997).

Історичний трактат свідчить, що у другій половині XVII ст., почалося зведення пожежних веж у таких містах як:

Івано-Франківську (1672 рік) було зведено ратушу з якої контролювалися спалахи пожежі; на Тернопільщині, а саме у селищі Гусятин (1634 рік) Довкола вежі по верху йшла галерея, там постійно чатували дозорці. При виявленні пожежі, наближення ворога чи будь-яких інших небезпек спостерігачі трубили у сурми, попереджаючи мешканців міста. Для цих вартових над годинником була обладнана кімната, де вони й мешкали.

Далі історичний ланцюг свідчить про те, що активний розвиток пожежних веж припадає на XIX століття.

У Луцьку одна із перших згадок про службу боротьби з вогнем датується 1807 роком. Дещо пізніше, майже через три десятиліття, в 1835-37 роках був розроблений проект пожежної будівлі з теплою хатою та каланчею (Беєр, 1979).

Місто Миколаїв. Хоча у давні часи не був дуже великим містом, професійні пожежні все ж постійно у ньому відбувалися. Тому у 1810 році було збудовано Управу, в якій з'явилася перша каланча. Крім того, в Управі розміщувалася Дума, Сирітський суд, поліція, Міський банк і Міський архів.

Харківщина. 1845 рік. Була побудована Залочанська пожежна частина Будівля мала три поверхи з одноповерховими добудовами і вежею-каланчею висотою 34 метри. 
Через три роки, а саме у 1848 році в центрі Чернівців постала велична будівля на третьому поверсі якої розмістилася пожежна вежа.

Проаналізувавши літературні джерела можемо зрозуміти, що Державне регулювання питань пожежної безпеки відіграло важливу роль у подальшому вдосконаленні системи державного управління. Так владою Києва у 1835 році вводиться посада брандмейстера, а в 1841 організовується перша пожежна частина - Старокиївська. Лише через десять років, а саме у 1850-тих рр., була збудована перша пожежна вежа. До 70-х рр., ХІХ ст., в Києві було 4 пожежних частини: Печерська, Дворцова, Старокиївська й Подільська. Але потім, у зв'язку зі зростом пожеж, в Либідській частині міста була створена Либідська пожежна частина, де були розташовані будинки, фабрики й заводи заможних і впливових купців.

Пожежна охорона Київської області була започаткована у Білій Церкві графами Браницькими у середині X1X сторіччя i була організована чи не найкраще на теренах губернії. Пізніше у м. Тараща, Київської області (80-90-ті рр.). На початку ХХ ст., свої пожежні вежі збудували такі українські міста як Звенигородка, містечко, що відносилося до Київської губернії (1900 рік), (Щербина, 1970).

Перші відомості про існування пожежної охорони на Рівненщині відносяться також до Х1Х ст., (1865 рік). Саме тоді в Рівному була утворена громадська пожежна управа iз залученням мешканців міста до обов'язкового відбуття повинностей у справі гасіння вогню.

Тернопіль (1884 рік).

Перші документальні відомості про організовану пожежну охорону в Сумах датуються 1888 роком. На той час функціонували дві пожежні частини, які пізніше об’єднали у громадську пожежну команду.

Житомирщина (1894 рік). Будівля мала одноповерхову казарму, де проживав загін вогнеборців. У сьогоденні $\epsilon$ пам'яткою архітектури місцевого значення. У музеї 
представлена історія формування системи пожежогасіння та пожежної техніки, на кінопроекторі показують фільм про причини виникнення пожеж.

У 1898 - 1899 роках на Поштовій вулиці м. Херсон для пожежного депо було побудовано нове приміщення, що включало квартиру брандмайстра і пожежну каланчу, з якою цілодобово велося спостереження.

Пожежна охорона міста Львова була організована на основі рішення магістрату від 4 січня 1849 року з ініціативи бургомістра Карла Гьопфлінгена-Бергендорфа, та є однією 3 найстаріших організованих пожежних структур на теренах нинішньої України. Офіційне відкриття каланчі відбулося 1901 року, хоча згадки про наглядачів пожежного порядку існують 3 XVI ст.

Новгород-Сіверський, Чернігівської області (1901 рік), з часом Чернігів (1913 рік).

У Вінниці (1902 рік), було розпочато будівництво водогону. Оскільки споруда була найвищою у місті, то на іiі горищі облаштували невеликий майданчик 3 будкою для пожежних цілей.

Маріуполь (1910 рік), збудована водонапірна башта. До цієї споруди, ближче до джерела води, перевели пожежну частину, яка була заснована в Маріуполі після міської реформи ще у 1872 році. 3 того часу вежу використовували і як пожену каланчу, м. Балта на Одещині (1925 рік), Кременчук (1939 рік) та місто Хмельницький (1954 рік).

За свідченнями історичних літературних джерел на вежах (каланчах) пожежної частини завжди чергував постовий, який спостерігав за міськими вулицями. У разі виявлення пожежі черговий бив у дзвін певну кількість ударів з інтервалом, що було сигналом для пожежної команди, яка знаходилася внизу станції або вивішувалися на каланчі умовні знаки (прапори, шари, хрести) і доповідалося про це брандмейстеру, з дозволу якого частина виїжджала на пожежу (Бокшиц, 2018). Такий вид спостереження та запобігання виникнення пожеж було 
довготривалий час основним засобом виявлення та повідомлення про пожежу.

В подальшому, важливим удосконаленням iз організаційної діяльності у питаннях пожежної справи в Україні стало прийняття Сенатом Російської імперії Будівельного та Пожежного статутів у 1832 році. Нормативноправові акти визначали правила у сфері пожежної безпеки, якими унормовувалося питання профілактики (запобігання) виникнення пожеж та організації заходів (реагування) їх гасіння, встановлювалась відповідальність за невиконання положень статутів.

Після зміни в 1917 р. політичного устрою розпочався новий процес державного будівництва, в якому посідало відповідне місце питання пожежної безпеки та пожежної охорони. Державне управління сферою пожежної безпеки у радянські часи почалось у 1918 р. із підписання декрету Ради Народних Комісарів «Про організацію державних мір боротьби 3 вогнем». У ньому були викладені організаційні основи радянської пожежної охорони, поставлені завдання забезпечення пожежної безпеки в країні, передбачено створення та розвиток професійних організацій і добровільних пожежних формувань, залучення широких колів громадськості до справи попередження та гасіння пожеж, підготовка кадрів $і$ розгортання відповідних науково-дослідних робіт (Щербина, 1970).

Співставляючи факти минулого та сучасного розвитку пожежної безпеки бачимо, що нині модернізація пожежної справи як в Україні так і у світі в цілому прогресивно розвинулася.

Минуле чатування вогню на пожежних вежах змінилося на оперативні звістки телекомунікаційних та інформаційних повідомлень, що дає змогу швидко відреагувати і запобігти тяжким матеріальним збиткам та головне врятувати життя людей. 
Висновки. Головна мета освітньо-виховного процесу дисциплін безпекового циклу - це оволодіння здобувачами вищої освіти конкретними знаннями та бажання здобувати нові вміння, відкривати їх для себе самостійно, користуючись сучасними інформаційними технологіями на прикладах історичних фактів.

Сучасним закладам вищої освіти необхідно забезпечити такий рівень підготовки випускників, який би відповідав державним освітнім стандартам. Сучасний розвиток науки i техніки висуває вимоги по розробці відповідних методів навчання, впровадження нових ефективних форм підготовки фахівців, здатних ефективно виконувати завдання за призначенням, у тому числі і з питань пожежної безпеки.

У результаті дослідження історичного підгрунтя щодо виникнення розвитку у сфері пожежної безпеки, встановлено, що в міру розвитку людського суспільства, 3 пізнанням властивостей вогню змінювалося і його сприйняття людиною та державою. Вирішення питань пожежної безпеки та управління ii станом 3 боку держави здійснювалося в залежності від різних факторів у межах відповідних цивілізацій.

Отже у сучасних вищих освітніх закладах саме формування знань і навчання заходам пожежної безпеки $\epsilon$ основним чинником у попередженні пожеж, а формування культури пожежобезпечної поведінки - основою правильного усвідомлення небезпеки пожеж i недопущення пожежонебезпечних ситуацій у майбутньому. Тому доречним буде стверджувати, що знання історичних подій щодо розвитку пожежних веж та пожежної охорони є суттєвою ланкою для формування знань у здобувачів вищої освіти 3 пожежної безпеки виробництв.

\section{ДЖЕРЕЛА ТА ЛІТЕРАТУРА}

1. Бэйр У. Основы противопожарной безопасности. Пер. с англ. Москва: Стройиздат, 1979. 124 с. 
2. Бєзуглов О.Є., Колєнов О.М., Іщук В.М. Первинна підготовка пожежного-рятувальника. Навч. посіб. 3 дисципліни: «Первинна підготовка рятувальника». Харків: НУЦЗУ, 2012. С. 11-15.

3. Бокшиц О.M. Формування здоров'язберігаючої компетентності студентської молоді у ході вивчення дисципліни «пожежна безпека виробництв». ПереяславХмельницький (Київ. обл.): Домбровська, 2018. С. 40-55.

4. Бокшиц О.М. Історичні аспекти виникнення та тенденції розвитку пожежного захисту населення початок XVIII - кінець XIX століття. Науковий часопис. Нац. пед. ун-т ім. М.П. Драгоманова. Київ: Вид-во НПУ ім. М.П. Драгоманова, 2015. Вип. 52. С. 26-32.

5. Бокшиц О.М. Компетентнісний підхід та особливості викладання дисципліни «Пожежна безпека виробництв» у ВНЗ. Ключові компетентності в моделі сучасного фахівия - 2016: Тези III Міжнар. науково-практичної інтернет-конференції (м. Переяслав-Хмельницький, 29 лютого 2016 р.) Наук. ред. O.I. Шапран; ДВНЗ «Переяслав-Хмельницький державний педагогічний університет імені Григорія Сковороди». Переяслав-Хмельницький: ФОП Домбровська Я.М., 2016. Ч. І. $279 \mathrm{c}$.

6. Бокшиц O.M., Каменська I.C. Дидактичні умови використання нових інформаційних технологій у вивченні пожежної безпеки виробництв у ВНЗ. Науковий огляд. Научный обзор. Scientific review. 2016. №9 (30) C. 77-90.

7. Борис О.П. Історія становлення державної пожежної охорони та їі роль у формуванні системи цивільного захисту України. Електронний журнал «Державне управління: удосконалення та розвиток». № 1, 2017.

8. Доманський В.А. Державне управління пожежною безпекою України (організаційно-правовий аналіз за матеріалами діяльності державного департаменту пожежної безпеки) : автореф. дис. ...канд. юр. наук: 12.00.07. Київ, 2004. $24 \mathrm{c}$. 
9. Зеркалов Д.В. Безпека життєдіяльності. Київ: Основа, 2011. $526 \mathrm{c}$.

10. Нехаев В. С. Огнеборцы Запорожья. Запорожье: ИПК «Запоріжжя», 1997. 316 с.

11. Панченко Т. Фактори формування правової компетентності майбутніх офіцерів. Сучасні тендениії розвитку професійної освіти в Європейському просторі. Черкаси : ПП Гордієнко, 2013. С. 134 - 137.

12. Підгайний А.В. Становлення та розвиток системи підготовки офіцерських кадрів МНС України наприкінці XX початку XXI століття : автореф. дис. ...канд. іст. наук : 20.02.22. Львів, 2009. 20 с.

13. Пожежна безпека: теорія i практика. Черкаси: АПБ ім. Героїв Чорнобиля НУЦЗУ, 2014. №18. 176 с.

14. Рожков А. П. Пожежна безпека. Київ: Пожінформтехніка, 1999. $256 \mathrm{c}$.

15. Смирнов Г. В. Историческая хроника пожарной охраны Луганска. Луганск: Изд-во «Лугань», 1996. 416 с.

16. Томіленко А. Г. Історія пожежно-рятувальної служби України (від зародження до 1917 р.). Черкаси: АПБ імені Героїв Чорнобиля, 2014. $220 \mathrm{c}$.

17. Щербина Я. Я. Основы противопожарной техники. Київ: «Вища школа», 1970. 212 с.

\section{REFERENCES}

1. Beyr. U. (1979). Osnovy protivopozharnoy bezopasnosti [Fundamentals of fire safety]. Moskva: Stroiyzdat [in Ukrainian].

2. Biezuhlov, O.Ye., \& Kolienov, O.M., Ishchuk, V.M. (2012). Pervynna pidhotovka pozhezhnoho-riatuvalnyka [Initial training of a firefighter-rescuer] Kharkiv: NUTsZU [in Ukrainian].

3. Bokshyts, O.M. (2018). Formuvannia zdorov'iazberihaiuchoi kompetentnosti studentskoi molodi u khodi vyvchennia dystsypliny "pozhezhna bezpeka vyrobnytstv» [Formation of health-preserving competence of student youth during the study of the discipline "fire safety of industries»]. Pereiaslav-Khmelnytskyi (Kyiv. obl.): Dombrovska [in Ukrainian]. 
4. Bokshyts, O.M. (2015). Istorychni aspekty vynyknennia ta tendentsii rozvytku pozhezhnoho zakhystu naselennia pochatok VIII - kinets XIX stolittia. [Historical aspects of the origin and trends of fire protection of the population beginning of the XVIII end of the XIX century]. Kyiv: Vyd-vo NPU im. M.P. Drahomanova [in Ukrainian].

5. Bokshyts, O.M. (2016). Kompetentnisnyi pidkhid ta osoblyvosti vykladannia dystsypliny «Pozhezhna bezpeka vyrobnytstv» u VNZ. [Competence approach and features of teaching the discipline «Fire safety of production» in higher education] (pp. Kliuchovi kompetentnosti v modeli suchasnoho fakhivtsia-Key competencies in the model of a modern specialist, 279 [in Ukrainian].

6. Bokshyts, O.M., \& Kamenska, I.S. (2016). Dydaktychni umovy vykorystannia novykh informatsiinykh tekhnolohii $\mathrm{u}$ vyvchenni pozhezhnoi bezpeky vyrobnytstv u VNZ. [Didactic conditions for the use of new information technologies in the study of fire safety in industrial institutions]. Naukovyi ohliad-Scientific review. №9 (30) 77-90 [in Ukrainian].

7. Borys, O.P. (2017). Istoriia stanovlennia derzhavnoi pozhezhnoi okhorony ta yii rol u formuvanni systemy tsyvilnoho zakhystu Ukrainy [History of formation of the state fire protection and its role in formation of system of civil protection of Ukraine] №1 [in Ukrainian].

8. Domanskyi, V.A. (2004). Derzhavne upravlinnia pozhezhnoiu bezpekoiu Ukrainy (orhanizatsiino-pravovyi analiz za materialamy diialnosti derzhavnoho departamentu pozhezhnoi bezpeky) [State management of fire safety of Ukraine (organizational and legal analysis on materials of activity of the state department of fire safety)] Candidate's thesis. Kyiv [in Ukrainian].

9. Zerkalov, D.V. (2011). Bezpeka zhyttiediialnosti [Life Safety]. Kyiv: Osnova [in Ukrainian].

10. Nekhaev, V. S. (1997). Ognebortsy Zaporozh'ya. [Firefighters of Zaporozhye]. Zaporozhe: YPK «Zaporizhzhia» [in Ukrainian]. 
11. Panchenko, T. (2013). Faktory formuvannia pravovoi kompetentnosti maibutnikh ofitseriv [Factors of formation of legal competence of future officers]. Suchasni tendentsii rozvytku profesiinoi osvity v Yevropeiskomu prostori - Current trends in the development of vocational education in the European space 134137 [in Ukrainian].

12. Pidhainyi, A.V. (2009). Stanovlennia ta rozvytok systemy pidhotovky ofitserskykh kadriv MNS Ukrainy naprykintsi XX pochatku XXI stolittia/ [Formation and development of the system of officer training of the Ministry of Emergencies of Ukraine in the late XX - early XXI century] Candidate's thesis. Lviv [in Ukrainian].

13. Pozhezhna bezpeka: teoriia i praktyka [Fire safety: theory and practice]. (2014). Cherkasy: APB them. Heroes of Chernobyl NUTSZU. №18. $176 \mathrm{~s}$.

14. Rozhkov, A. P. (1999). Pozhezhna bezpeka [Fire safety]. Kyiv: Pozhinformtekhnika [in Ukrainian].

15. Smyrnov, H. V. (1996). Ystorycheskaia khronyka pozharnoi okhranbl Luhanska [Historical chronicle of fire protection of Lugansk]. Luhansk: Yzd-vo «Luhan» [in Ukrainian].

16. Tomilenko, A. H. (2014). Istoriia pozhezhno-riatuvalnoi sluzhby Ukrainy (vid zarodzhennia do 1917 r.) [History of the fire and rescue service of Ukraine (from its inception to 1917)] Cherkasy: APB imeni Heroiv Chornobylia [in Ukrainian].

17. Shcherbyna, Ya. Ya. (1970). Osnovy protivopozharnoy tekhniki. [Fundamentals of firefighting equipment]. Kyiv: «Vyshcha shkola» [in Ukrainian].

\section{АНОТАЦІЯ}

У реаліях сучасного сьогодення здоров'я - ие основна фундаментальна ланка в житті кожної людини, яка безпосередньо відображається на ї̈ буття, благополуччя, психічне та емочійне самопочуття. Здоров'я $\epsilon$ иінним показником циивілізованості сучасного суспільства, одним із основних складників національного розвитку у цілому світі. 
У складних умовах пандемії, щз відбувається нині у світі, сучасне суспільство все ж потребує компетентних фахівців, які могли б бути конкурентоспроможними на ринку праці, рімуче змінювалися б $і$ організовували активну жсттєву позицію, які швидко приймали б логічні поставленій меті рішення, уміли раціонально організовувати свою життєдіяльність із позицій збереження, зміцнення здоров'я як свого, так $i$ оточуючих, створювати $i$ забезпечувати безпечні умови життя та праці на виробництві та в побуті, вміти запобігати небезпечним ситуаціям, щзо загрожують життю людей.

Відомо, щуо пожежна небезпека одна із найстаріших загроз та проблем із якою стикається людство протягом всього земного життя.

Вогонь залишив свої сліди в історії всіх епох і народів. Тисячі міст і сіл зникли з лиця Землі в гігантських язиках полум'я. Безцінні витвори розуму і талановитих рук попередніх поколінь перетворилися на порох. Протягом всіх століть вогонь знищував мільйони людських життів. За своїми трагічними наслідками пожежі не поступалися епідеміям, посухам та іншим лихам.

Загальна кількість пожеж на нашій планеті досягла 5,5 млн на рік, кожні 5 секунд десь спалахує пожежа. Тому не дивно, щуо сьогодні пожежі дійсно все частіше стають вагомою проблемою.

У нинішніх реаліях XXI століття сучасна людина вже озброєна знаннями й найпотужнішою технікою, $i$ вже може на належному рівні конкурувати з вогнем, здобувати та формувати знання про пожежну безпеку, знання, які отримуються у закладах вищуӧ освіти. Саме у закладах вищої освіти відбувається формування знань, підготовка майбутніх фахівців професійного спрямування як пропагандистів $i$ педагогів у боротьбі з пожежами та безпечної організачії життєдіяльності. 
У статті розглядаються історичні моменти виникнення та розвитку на території України архітектурних пам'яток, які в свої часи виконували вагому роль та функиію з безпеки життя українського народу і слугували пожежними вежами (каланчами). Розкривається сутність формування знань 3 пожежної безпеки виробництв при вивченні історичних аспектів розвитку пожежних веж на території України.

Формування знань у студентів закладів вищої освіти з пожежної безпеки виробництв забезпечує розвиток умінь та навичок, здатності (компетениій) для здійснення ефективної професійної діяльності иляхом забезпечення оптимального управління пожежної безпеки на підприємствах (об'єктах господарської, економічної та науково-освітньої діяльності), формування у студентів відповідальності за особисту та колективну безпеку, розвиток здоров'язберігаючих компетенцій $i$ усвідомлення необхідності обов'язкового виконання в повному обсязі всіх заходів гарантування безпеки прачі на робочих місчяя.

Саме навчальні заклади зокрема вищі, незалежно від видів їх спрямованості, є тим иентром, де відбувається формування знань, умінь і навичок у студентів при вивченні пожежної безпеки зокрема. Людина з вищою освітою, яка має високий рівень здоров'язберігаючої компетентності, $\epsilon$ пропагандистом здорового способу життя та спрямовує свої знання й уміння на безпечні умови прачі.

Ключові слова: формування знань, студенти, дисципліна, пожежна безпека, заклад вищої освіти, каланча, пожежа.

\section{АННОТАЦИЯ}

В реалиях современного настоящего здоровье - это основное фундаментальное звено в жизни каждого человека, непосредственно отражается на его бытие, благополучие, психического и эмочионального самочувствия. Здоровье является ценным показателем циивилизованности современного общества, одним из основных составляющих национального развития во всем мире. 
В сложных условиях пандемии, что происходит сейчас в мире, современное общество все же нуждается в компетентных специиалистов, которые могли бы быть конкурентоспособныли на рынке труда, решительно менялись бы и организовывали активную жизненную позицию, быстро принимали бы логические поставленной цели решения, умели рационально организовывать свою жизнедеятельность с позииий сохранения, укрепления здоровья как своего так и окружающих, создавать и обеспечивать безопасные условия жизни и труда на производстве и в быту, уметь предотвращуать опасные ситуаџии, угрожающче жизни людей.

Известно, что пожарная опасность одна из старейших угроз и проблем с которой сталкивается человечество на протяжении всей земной жизни.

Огонь оставил свои следы в истории всех эпох и народов. Тысячи городов и сел исчезли с лища Земли в гигантских языках пламени. Бесченные произведения ума и талантливых рук предылущуих поколений превратились в прах. $B$ течение всех веков огонь уничтожал миллионы человеческих жизней. По своим трагическим последствиям пожары не уступали эпидемиям, засухам и другим бедствиям.

Общее количество пожаров на нашей планете достигла 5,5 млн. в год, каждые 5 секунд где-то вспыхивает пожар. Поэтому неудивительно, что сегодня пожары действительно все чащуе становятся важной проблемой.

В нынешних реалиях XXI века современный человек уже вооружен знаниями и мощиой техникой, и уже может на должном уровне конкурировать с огнем, получать $и$ формировать знания о пожарной безопасности, знания, получаемые в учреждениях высшего образования. Именно в учреждениях высшего образования происходит формирование знаний, подготовка будущуих специиалистов профессионального направления как пропагандистов и педагогов в борьбе с пожарами и безопасной организации жизнедеятельности. 
В статье рассматриваются исторические моменты возникновения и развития на территории Украинь архитектурных иенностей, которые в свои времена выполняли важную роль и функцию по безопасности жизни украинского народа и служили пожарныли вылками (каланчами). Раскрывается сущзность формирования знаний по пожарной безопасности производств при изучении исторических аспектов развития пожарных башен на территории Украиньл.

Формирование знаний у студентов высших учебных заведений по пожарной безопасности производств обеспечивает развитие умений и навыков, способности (компетенциий) для осущзествления эффективной профессиональной деятельности путем обеспечения оптимального управления пожарной безопасности на предприятиях (объектах хозяйственной, экономической и научно-образовательной деятельности), формирование в студентов ответственности за личную и коллективную безопасность, развитие сохраняющих здоровье компетенциий $u$ осознание необходимости обязательного выполнения 6 полном объеме всех мероприятий обеспечения безопасности труда на рабочих местах.

Именно учебные заведения в частности высшие, независимо от видов их направленности, являются тем цуентром, где происходит формирование знаний, умений и навыков у студентов при изучении пожарной безопасности в частности. Человек с высшим образованием является пропагандистом здорового образа жизни и направляет свои знания и умения на безопасные условия труда.

Ключевые слова: формирование знаний, студенты, дисциилина, пожарная безопасность, учреждение высшего образования, каланча, пожар. 